\title{
Research Article: Impact and assessment of agro processing based self-help groups in Nagpur district of Maharashtra
}

M.R. SHAIKH AND M.M. KADAM

Article Chronicle: Received :

12.08.2017;

Revised :

17.09.2017;

Accepted :

04.10.2017

KeY Words:

Self-help groups, Impact, Assessment

Author for correspondence :

\section{M.R. SHAIKH}

College of Agriculture, Alani, OSMANABAD

(M.S.) INDIA

Email:skmohasin21@

gmail.com

See end of the article for

authors' affiliations
SUMMARY : Microfinance is effective tool for poverty alleviation. Microfinance is defined as "Provision of thrift, credit and other financial services and product of very small amount to poor in rural, semiurban and urban areas for enabling them to raise their income level and improve living standards". The objectives of study were as follows, to study characteristics of self-helpgroups, to study economics of selected activities of self-help groups, to study employment generated through self-help groups and to study marketing system of different self-help groups. The study covers the Nagpur districts in the Maharashtra state. Three tahsils viz., Nagpur, Katol, Mouda out of the thirteen tahsils in district on the basis of more development of SHG movement in that tahsils compared to other. The study concluded, average age group of about 53.34 per cent SHGs were from 3-5 years. Majority (66.34 \%) of SHGs were of same castes. SHGs with 5 to 10 number of members were in majority $(56.66 \%)$. Non-insured members were more $(58.91 \%)$ than Insured members (41.09\%) in selected SHGs.Majority of SHG members were literate (about $75.35 \%$ ) Recovery performance of Bank loan (54.85\%) from SHG found better than Internal lending (53.77\%), but in overall both were not satisfactory. Pickle (C-B ratio 1:1.77) and Papad (C-B ratio 1:1.50) selfhelp groups showed highest cost benefit ratio. Consumer (direct channel) had highest 'producers' share in consumer's rupee' in all selected activities.

How to cite this article : Shaikh, M.R. and Kadam, M.M. (2017). Impact and assessment of agro processing based self-help groups in Nagpur district of Maharashtra. Agric. Update, 12(4): 634-638; DOI : 10.15740/HAS/ AU/12.4/634-638. 